\title{
Artificial gametes: perspectives of geneticists, ethicists and representatives of potential users
}

Citation for published version (APA):

Cutas, D., Dondorp, W., Swierstra, T. E., Repping, S., \& de Wert, G. (2014). Artificial gametes:

perspectives of geneticists, ethicists and representatives of potential users. Medicine Health Care and Philosophy, 17(3), 339-345. https://doi.org/10.1007/s11019-013-9535-8

Document status and date:

Published: 01/01/2014

DOI:

10.1007/s11019-013-9535-8

Document Version:

Publisher's PDF, also known as Version of record

Document license:

Taverne

Please check the document version of this publication:

- A submitted manuscript is the version of the article upon submission and before peer-review. There can be important differences between the submitted version and the official published version of record.

People interested in the research are advised to contact the author for the final version of the publication, or visit the DOI to the publisher's website.

- The final author version and the galley proof are versions of the publication after peer review.

- The final published version features the final layout of the paper including the volume, issue and page numbers.

Link to publication

\footnotetext{
General rights rights.

- You may freely distribute the URL identifying the publication in the public portal. please follow below link for the End User Agreement:

www.umlib.nl/taverne-license

Take down policy

If you believe that this document breaches copyright please contact us at:

repository@maastrichtuniversity.nl

providing details and we will investigate your claim.
}

Copyright and moral rights for the publications made accessible in the public portal are retained by the authors and/or other copyright owners and it is a condition of accessing publications that users recognise and abide by the legal requirements associated with these

- Users may download and print one copy of any publication from the public portal for the purpose of private study or research.

- You may not further distribute the material or use it for any profit-making activity or commercial gain

If the publication is distributed under the terms of Article $25 \mathrm{fa}$ of the Dutch Copyright Act, indicated by the "Taverne" license above, 


\title{
Artificial gametes: perspectives of geneticists, ethicists and representatives of potential users
}

\author{
Daniela Cutas - Wybo Dondorp • Tsjalling Swierstra • \\ Sjoerd Repping $\cdot$ Guido de Wert
}

Published online: 20 December 2013

(C) Springer Science+Business Media Dordrecht 2013

\begin{abstract}
Several threads of research towards developing artificial gametes are ongoing in a number of research labs worldwide. The development of a technology that could generate gametes in vitro has significant potential for human reproduction, and raises a lot of interest, as evidenced by the frequent and extensive media coverage of research in this area. We have asked researchers involved in work with artificial gametes, ethicists, and representatives of potential user groups, how they envisioned the use of artificial gametes in human reproduction. In the course of three focus groups, the participants commented on the various aspects involved. The two recurring themes were the strength of the claim of becoming a parent genetically, and the importance of responsible communication of science. The participants concurred that (a) the desire or need to have genetic offspring of one's own does not warrant the investment of research resources into these technologies, and that (b) given the minefield in terms of moral controversy and sensitivity that characterises the issues involved,
\end{abstract}

D. Cutas $(\varangle) \cdot$ W. Dondorp · G. de Wert

Department of Health, Ethics and Society, Maastricht

University, Maastricht, The Netherlands

e-mail: daniela.cutas@philos.umu.se

D. Cutas

Department of Historical, Philosophical and Religious Studies, Umeå University, Umeå, Sweden

T. Swierstra

Department of Philosophy, Maastricht University, Maastricht, The Netherlands

\section{S. Repping}

Centre for Reproductive Medicine, University of Amsterdam, Amsterdam, The Netherlands how information is communicated and handled is of great importance.

Keywords Artificial gametes - Assisted reproductive technologies (ARTs) · Genetic relatedness · Infertility · ICSI $\cdot$ Communication of research

\section{Study question}

What are the views of researchers and clinicians working with artificial gametes, of ethicists with a history of reflecting on such issues, and of representatives of potential user groups, about advancements in the generation and future use of artificial gametes?

\section{Introduction}

Artificial gametes are sperm and eggs generated in vitro from other types of cells: either human embryonic stem cells (ESC) or induced pluripotent stem cells (iPSC). According to a more broad understanding of artificial gametes, these also include, for example, follicles, oocytes or sperm matured in vitro. Our research and subsequently the present paper have focused on the former, and more narrow understanding of, and usually referred to as, artificial gametes.

Several directions of research are currently being pursued towards obtaining viable artificial gametes. These have varying degrees of reported success, and are surrounded by a considerable amount of controversy both from within and from outside of the scientific community. Research is ongoing with reprogramming of ESC as well as induced stem cells (iPSC). In recent years, the ability to 
generate live offspring from artificial gametes has been successfully employed in the mouse (Hayashi et al. 2011, 2012). More specifically, it has been demonstrated that from ESCs as well as from iPSCs it is possible to generate spermatogonial stem cells (that upon transplantation to the testis can make functional sperm) as well as functional oocytes. Further down the road is the generation of functional gametes of the other sex from ESCs or iPSCs, i.e. obtaining eggs from cells taken from males and sperm from cells from females (Highfield 2008; Cyranoski 2013). These are just a few examples of research that is going on in this area; whilst other research projects are being undertaken in labs across the world (White et al. 2012; Kerkis et al. 2011; Hinxton Group 2008; Heindrycks et al. 2007).

The interest to generate artificial gametes stems mainly from attempts to treat human infertility. In case of male infertility, half of all men with no sperm cells in their ejaculate, i.e. azoospermia, do not have any mature gametes in their testis that could be used for testicular sperm extraction (TESE) and subsequent intra cytoplasmic sperm injection (ICSI). These men are unable to have their own biological children. The development of artificial gametes, e.g. by transforming skin fibroblasts into iPSCs that could subsequently be turned into spermatogonial stem cells or even mature sperm, would allow them that. Almost all women will eventually become infertile due to the loss of oocyte quality and subsequent loss of the oocyte pool. In some cases, this 'ovarian failure' comes at an early stage, sometimes even before the age of twenty. Here also, the generation of artificial oocytes could allow women who do not have an ovarian reserve anymore to have their own children. Besides these classical cases, artificial gametes could theoretically also allow same sex couples to have offspring by generating sperm cells from female cells or by generating oocytes from male cells. Same sex couples currently have no way of reproducing together.

Furthermore, the generation of artificial gametes would allow the study of male and female gametogenesis in vitro. Currently, research into causes of male and female infertility is hampered by the absence of such in vitro models. As a consequence, it is virtually impossible to study, at least in humans, the functional consequences of for instance genetic mutations that are thought to underlie infertility. The ability to study gametogenesis in vitro would thus contribute significantly to our understanding of the causes of infertility and perhaps open new avenues to develop novel treatment strategies.

Against this background, we invited clinicians and geneticists working in reproductive genetics, ethicists, and representatives of potential users groups, to participate in focus groups on the topic of the possibilities for human reproductive use of these technologies.

\section{Method}

In September 2012, we conducted three focus groups with (1) clinicians and geneticists, (2) ethicists (philosophers), and (3) potential user representatives, respectively. ${ }^{1}$ GDW moderated the first focus group, and WD the other two. DC was observer at all three. Each meeting lasted approximately $2 \mathrm{~h}$, and was video recorded digitally and subsequently transcribed verbatim. We performed thematic analysis on the data thus obtained. This has been a small scale exercise (the groups had 4, 3, and 4 participants, respectively) and its results are to be treated accordingly.

\section{Results}

Participating researchers and clinicians were in agreement that the use of iPSC derived gametes in reproduction is a long way in the future-further away than predicted in the Hinxton Group Consensus Statement in 2008-if ever possible. Moreover, it is likely to be a by-product of ongoing gametogenesis research, rather than a first motive for undertaking the research. Indeed in this perspective they viewed the use of iPSC derived gametes much more positively than they did the idea of the need or desire of prospective parents to have genetically related children as a motive for research efforts. This is because of the principle of proportionality:

With a limited amount of resources, can you ethically shift funds from cancer research to infertility treatment?

asked one participant. Specifically to the issue of the case of same sex couples being able for the first time to reproduce with each other, the same participant pointed out that "there are different ways for them to become parents" (other than to become genetic parents together).

Some of the discussion highlighted differences between countries in availability of donated gametes and embryos: for example, in Spain there are more gametes and embryos than there are research projects to use them-moreover, the supply of gametes is sufficient for the demand in reproduction, thus invalidating the claim that artificial gametes are needed in reproduction. At this point the participants again manifested their disagreement as to the strength of

\footnotetext{
1 The participants were Alison Murdoch (Newcastle University), Ana Veiga (University of Barcelona and ESHRE), Susana Chuva de Sousa Lopes (Leiden University), Niels Geijsen (Hubrecht Institute), Anna Smajdor (University of East Anglia), Torbjörn Tännsjö (University of Stockholm), Guido Pennings (Ghent University), José Knijnenburg (Freya), Ris Keizer (Freya and D.O.M.), Marijke Merckx ("The Lost Stork", Belgium), René van Soeren (COC Netherlands).
} 
the claim of some people to access technologies in order to have offspring.

When using iPSC to create gametes, the main problem is that one is trying to make the cells do something that they do not have the potential to do: human cells display a skewed developmental potential, that is, any human stem cell line has a preference to differentiate along a particular germ layer. According to one participant, this may mean that human pluripotent stem cells have progressed beyond the point where the germ line is formed, and while developing germ cells themselves undergo epigenetic reprogramming processes, the primed nature of the starting material may make it more difficult to generate fully functional gametes. In addition, early passages of iPSCs have been shown to have some epigenetic 'memory' of the cell type from which they were derived. This too could hamper the use of cells derived from, for example, skin cells, to make a fully functional human gamete, but prolonged passaging of the human iPSCs may solve this problem.

There was disagreement over whether such limitations could ever be overcome, or whether that would be a wise development. Related issues of the ethics of communicating research were also touched upon, as the participants expressed concerns (accompanied by examples of recent cases) about raising false hopes among potential users when reporting research results in this area. One participant objected to the term "artificial gametes", pointing out that it suggests something plasticky or completely made-up: which they are not, inasmuch as we are talking about human cells. The language of artificial returned towards the end of the meeting, when another participant said that a problem with trying to make a cell do what it doesn't want to do (in this case, become a gamete) is that it would be artificial.

That human beings might eventually be created from artificial gametes raised some discussion, with one of the participants concluding that, ultimately, "if you want to understand, you have to create it. If you want to understand how good an egg is, you have to fertilise".

According to the participants to the second focus group, should it become possible to create children from people's skin cells, then the need to redefine parenthood would be even more pressing: for example, because of the issues involved in attributing legal parental responsibility. There was disagreement among the participants on this aspect: according to another participant, what is needed are clear procedures that insure that the identity of everyone involved is known and informed consent is taken from all relevant parties, whether it is donor gametes or artificial gametes that are involved. Another closely related difficulty here might be that, should children be created from, for example, eggs obtained from men, they would be born in very unusual situations. According to one participant, however,

... in fact why can't you say that you have genetically two mothers. We are creating problems by applying an old framework to a new situation. I do not believe that this is going to be a major issue. (...) rationally we should be able to say this is your genetic female parent and this is your gestational parent and this is your male genetic parent, and that makes perfect sense, but people are trying to fit or exclude those people into their very rigid paradigms.

Closely related but wider issues that have been touched upon include the reliance on "survey ethics" (asking society members, whether or not these are correctly informed or concerned by the issue at hand) that some law-makers demonstrate, particularly in areas highly susceptible to the yuck factor such as are innovations and interventions on human reproduction. How an innovation is presented, then (for example, as fitting into an existing framework as opposed to "something different"), has a high impact on how it is going to be received by the public. The participants contributed examples from their own countries highlighting the importance of the rhetoric. Another of the examples taken is that of presenting infertility as a disease-which is more likely to incline society to refund treatments. However "infertility" itself is a tricky concept: in the words of one participant, insofar as infertility is concerned "the lesbians have the best case, women are completely azoospermic, women cannot produce sperm".

The principle of proportionality came up in this meeting also, one of the participants pointing out that

if the health service does say that everyone who wants a gamete has a need for a gamete, we're not going to have much money for anything else.

Another major aspect touched upon during the meeting is that of the difficulty of making the move from the theoretical stage or animal research stage into human research and human use, given current research regulations-which themselves differ between countries. The conclusion of the participants on this issue was that mostly this will be a matter of someone setting the precedent, which will open the door for regulatory change and for others to follow suit. As one participant put it,

I want to distinguish between what can be done and what should happen. Whether any country ought to wait to see what happens in other countries, I don't think that's a very good stance to take, it's cowardly and I think the countries who are thinking about this have to think about their own moral decisions, 
pragmatically I think what happens is that someone somewhere less regulated will do something that creates a precedent and then we will see people start to take it up.

The main issues discussed during the third focus group gravitated around: whether there is a right to have biologically related children (neither participant thought there was such a right); equal access to technology once it has been put to use; the unfairness of how infertility is perceived publicly in relation to other health issues, even equally non-fatal ones; the interest of the child; societal pressure to have children at all cost.

One participant pointed out that even though there is no such thing as a right to have offspring, once these technologies are available and offered to anyone, then people who are otherwise not necessarily infertile (such as gay and lesbian couples) should also be offered them-for reasons of equality and non-discrimination.

The participants commented extensively on why having a child genetically related to oneself is desired. We will here cite some of their comments:

(participant 1) You have a relationship, you want a child with that partner, I don't want to have a relationship whatever outside the relationship with that partner. You want to be genetically together, you want to have a child together, as a result of your love, your relationship. Women and men are different generally speaking in reproduction. Women have another drive, the drive to be mother, so basic for most of the women, it's hard to explain.

(participant 2) I think many homosexual couples would really like that, I have many lesbian couples who want to use the egg of one or that you can transplant the core of an egg... it's just the feeling to do it together and put the stuff of two people together and make one child. (...) People have different motives for having a child, not everyone's motive is the same. We want a child as a product of the two of us, my features and your features, something that comes from the heart and not from the head.

(participant 3) You become a bit immortal, and that's an instinct. (...) I had a small questionnaire among my patients and there is a difference between my head that wants a child and my heart that wants a child. There is a need to protect us against ourselves, because everybody says rationally no technique should go too far, there is a limit...

(participant 4) (...) There is of course an interfering factor, that there is someone outside your relationship who also has a social or legal right to your child, and that's why I think people want a genetic child, because once you have that nobody else messes with your child.

The desire for genetically related children was intertwined with comments that may point to additional reasons why one might seek ARTs in the desire to become a parent. According to one participant,

In the society in which we live now, for two people with physical disabilities, it's not allowed to foster children, to adopt children, so the only... Because people don't know how it is to live with a physical disability, the people who make the rules are not the people who have a physical handicap.

Thus, at least in some cases, the hurdles of ARTs are in fact the easier or only way of becoming a parent. Further, there was disagreement between the participants regarding elective older parenting-some arguing that this would be very difficult for the older mothers and that at the same time the age of the mother would make children feel different in an important aspect from their friends-and that is hard for them.

Societal pressure pushes people to go to extreme lengths to become parents. According to one participant,

Society gives you the pressure that if you want to have a child you have to do everything.

And, according to another participant,

If you don't do everything, you don't want hard enough. The more possibilities there are, the more pressure on people to try everything.

In the view of some of the participants, the prospect of the introduction of new reproductive technologies such as artificial gametes not only increases individual choice, but also restricts it by requiring people to go to even more extreme lengths if they are to be believed that they are really trying to become parents.

\section{Discussion}

The focus groups have been very instructive for us, particularly as the discussions seemed to converge on the same themes in all three groups, regardless of whether these had been explicitly asked or mentioned by the moderator. The main recurrent theme in all three focus groups was the importance of the genetic link between parents and children. The scientists and clinicians were overwhelmingly critical of claims that people have a fundamental interest in having offspring. The representatives of potential users' groups were much more sympathetic to such claims 
(though not all of them to the same extent). The ethicists (both from a utilitarian and a Kantian perspective) criticised the rationality and compellingness of claims made in the name of this desire. However, all participants agreed that the claim to have offspring does not warrant the investment of scarce scientific and financial resources into research on artificial gametes.

The discussions helped clarify the different aspects of the potential reproductive use of artificial gametes. We found that in their contributions, participants switched between technical feasibility, social acceptance or desire, and moral desirability of this particular technological application (Lucivero et al. 2011). We think it is important to differentiate between those three aspects more systematically. For example, the use of artificial gametes to become a parent may be deemed socially desired by some or many, but whether this application is technically feasible or morally desirable are different issues. With regard to moral desirability, it is not enough to point out that some or many people want this technology, but we also have to tackle questions such as whether this use of scarce resources would be just or proportionate.

The scientists and clinicians in our focus group were the most reserved with regard to the applicability of artificial gametes in human reproduction. However, it was not always clear whether they referred to the technological feasibility or moral desirability of this application. Although most of the participants in the first focus group were not enthusiastic about the prospect of creating artificial gametes for reproductive purposes, one of them stated, "I'm optimistic. Science fiction is interesting because it could happen, it's not completely impossible". And the most reserved scientist ("I don't think it works to use iPSC to create babies") qualified her statements during the discussions by saying 'I'm not saying it wouldn't be technically possible, but that it wouldn't be wise". As we can infer from this, the responses of the participants follow one or another aspect, and sometimes one answer may explicitly be about one aspect (technical possibility), but may be later qualified to pertain to whether or not certain applications of technologies would be wise (moral desirability).

Another recurring theme in the focus groups consists in the issue of (mis)communication of research innovations, and its likely consequences. The scientists and clinicians gave examples of unsubstantiated claims of success, published in research literature and further inflated in the media-which they saw as irresponsible communication of results. The ethicists pointed out the importance, for both public acceptance and policy-making, of how we communicate results: again, cautioning against emphasising the extraordinary character of research progress. The representatives of user groups criticised the overly optimistic presentation of new technologies that correlates with the underrepresentation of the suffering and low success rates, and the lack of support that users are confronted with.

The recurring, in all three focus groups, theme of the value of the genetic link between parents and children is particularly worth following up, for a variety of reasons. Firstly, looking at the history of the field, the importance of helping people to have a child of which both partners would be the genetic parents seems to have been taken for granted. An illustration of this is that there has hardly been any debate about the obviousness of the need to help couples with male factor infertility to have their genetically own child with intracytoplasmic sperm injection (ICSI) rather than reproduce with donor sperm, where doing so would be far more cost effective, if not for the absence of the genetic link with the male partner. A more recent example is the research effort behind developing nuclear transfer technology as a way of helping women at risk of having a child with a mitochondrial disease to have healthy offspring, whereas these women could also have children with donated eggs (Bredenoord et al. 2008; Nuffield Council of Bioethics 2012). If the prospect of creating artificial gametes does indeed lead to questioning this attachment to the value of the genetic link, it will have implications for the evaluation of current practices of assisted reproduction as well.

Secondly, taking account of previous statements by researchers working towards developing artificial gametes, it seems that the broad consensus among the participants in our focus group, as to the value of using artificial gametes in reproduction, is not representative across their profession. Looking at the reasons and expectations provided by scientists when they report work in this area, we can see that some list research-related purposes (Geijsen et al. 2004; West et al. 2006; Nayernia et al. 2006; Kerkis et al. 2011; Hayashi et al. 2012), whilst others explicitly emphasise the potential future uses of artificial gametes as such in human reproduction (Heindrycks et al. 2007; Deng et al. 2011). Note here that we are not looking at whether one of the outcomes may ultimately be the relief of infertility, but at the declared why's of current research with artificial gametes. Growth of knowledge of cell (and in particular gamete) development is relevant for fertility treatment, whether or not artificial gametes as such will eventually be used in human reproduction.

Another example of a mismatch between statements by the scientists in our focus group and by others is the claim that it is unlikely to ever obtain functional gametes from cells taken from for example skin tissue. The recent paper by Hayashi et al. (2012) claims just that: to have obtained, in mice, functional gametes from stem cells obtained from skin cells-and that the offspring produced from these gametes went on to produce viable offspring.

As inflated media reports of advancements in work with artificial gametes (in both the narrow and the broad sense) 
abound, proclaiming the end of infertility and eliciting a lot of attention, and as new technologies (such as egg vitrification: the fast freezing of eggs, making their preservation a much more feasible prospect than it used to be) hit the market, it will be interesting to follow how the attachment to genetic parenthood will be affected. After all, it is a common occurrence that the availability of the technological means affect the definition of the ends. What we want and claim is related to what technology can offer us. Looking at the comments by the participants in our third focus group, such prospects have the potential to both multiply the choices of people who try to become parents, and make it harder for them to not "do everything", as one of our participants put it. Moreover, for reasons of equal access, once such technologies are in use, then if they are being used in the case of heterosexual couples suffering from infertility, other potential user groups may also claim their entitlement to access (as was pointed out by a participant in our third focus group with reference to gay and lesbian prospective parents).

As a side note: the personal experiences of participants crept in at several times during the discussions, such as the fact that one participant was a parent via ICSI, one participant was the offspring of an older mother, one participant was the parent of six children (half of which her genetically own), and one participant's father was also his mother (if we correlate father with male parent and mother with female parent: the father in question was transgender). These experiences have enriched the discussions and added a personal layer that we had not planned. Additionally, although the groups were small, each time we have had at least two countries represented: the Netherlands, Belgium, Spain and the UK in the first focus group, Belgium, the UK and Sweden in the second group, and Belgium and the Netherlands in the third group. This has maintained the awareness of the different regulatory environments and resources available in different European countries..

\section{Conclusion}

This has been a small scale exercise, but it has produced some interesting findings. The participants had close connections to the issues under discussion and in this way, every single participant brought with her expertise or experience directly relevant for the questions to be discussed. The scientists and clinicians were themselves involved with work with artificial gametes, in their own research and some also policy-wise (as members in bodies overseeing or regulating such research). Participants in the second focus group have experience with tackling just this sort of questions, among others, in their research-as well as, again, as members of overseeing or regulatory bodies.
And lastly, all participants in our third focus group were experienced members of relevant organisations representing potential users.

The most frequently recurring theme during the three focus groups was the value of the genetic link between parents and children, and what it requires (or, rather, what it does not require). The second frequently recurring theme was the importance of responsible communication of research results and research results in the area of infertility in particular. Given the speed at which technology is developing in this area, it is in our view extremely important to have a timely investigation that thoroughly addresses the value of the genetic link between parents and children.

Acknowledgments We are very grateful to all focus group participants for their participation. The work reported in this paper has been made possible by the project "Artificial gametes: science and ethics", funded by the Centre for Society and the Life Sciences (CSG), Nijmegen, and the Netherlands Organisation for Health Research and Development (ZonMw), The Hague.

\section{References}

Bredenoord, A.L., G. Pennings, and G. de Wert. 2008. Ooplasmic and nuclear transfer to prevent mitochondrial DNA disorders: Conceptual and normative issues. Human Reproduction Update 14: 669-678.

Cyranoski, D. 2013. Stem cells: Egg engineers. Nature.

Deng, J.M., K. Satoh, H. Wang, H. Chang, Z. Zhang, M.D. Stewart, A.J. Cooney, and R.R. Behringer. 2011. Generation of viable male and female mice from two fathers. Biology of Reproduction 84: 613-618.

Geijsen, N., M. Horoschak, K. Kim, J. Gribnau, K. Eggan, and G.Q. Daley. 2004. Derivation of embryonic germ cells and male gametes from embryonic stem cells. Nature 427: 148-154.

Hayashi, K., H. Ohta, K. Kurimoto, S. Aramaki, and M. Saitou. 2011. Reconstitution of the mouse germ cell specification pathway in culture by pluripotent stem cells. Cell 146: 519-532.

Hayashi, K., S. Ogushi, K. Kurimoto, S. Shimamoto, M. Ohta, and M. Saitou. 2012. Offspring from oocytes derived from in vitro primordial cell-like cells in mice. Science 338: 971-975.

Heindrycks, B., P. De Sutter, J. Gerris, M. Dhont, and J. Van der Elst. 2007. Embryo development after successful somatic cell nuclear transfer to in vitro matured human germinal vesicle oocytes. Human Reproduction 22: 1982-1990.

Highfield, R. 2008. Sperm cells created from female embryo. The Telegraph.

Hinxton Group. 2008. Consensus statement: Science, ethics and policy challenges of pluripotent stem cell-derived gametes. http://www.hinxtongroup.org/au_pscdg_cs.html. Accessed September 2013.

Kerkis, I., C.M. Mendes, S.A.S. da Fonseca, N.F. Lizier, R.C. Serafim, and A. Kerkis. 2011. Actual achievements on germ cells and gametes derived from pluripotent stem cells. In Embryonic stem cells-recent advances in pluripotent stem cell-based regenerative medicine, ed. C. Atwood, 311-336. Rijeka: InTech.

Lucivero, F., T. Swierstra, and M. Boenink. 2011. Assessing expectations: toward a toolbox for an ethics of emerging technologies. Nanoethics 5: 129-141. 
Nuffield Council on Bioethics. 2012. Novel techniques for the prevention of mitochondrial DNA disorders. London: Nuffield Council. http://www.nuffieldbioethics.org/sites/default/files/Novel_techni ques_for_the_prevention_of_mitochondrial_DNA_disorders_ compressed.pdf. Accessed September 2013.

Nayernia, K., J. Nolte, H.W. Michelmann, J.H. Lee, K. Rathsack, N. Drusenheimer, A. Dev, G. Wulf, I.E. Ehrmann, D.J. Elliott, V. Okpanyi, U. Xechner, T. Haaf, A. Minhardt, and W. Engel. 2006. In vitro-differentiated embryonic stem cells give rise to make gametes that can generate offspring mice. Developmental Cell 11: 125-132.

West, J., I.-H. Park, G. Daley, and N. Geijsen. 2006. In vitro generation of germ cells from murine embryonic stem cells. Nature Protocols 1: 2026-2036.

White, W.A.R., D.C. Woods, Y. Takai, O. Ishihara, H. Seki, and J. Tilly. 2012. Oocyte formation by mitotically active germ cells purified from ovaries of reproductive-age women. Nature Medicine 18: 413-421. 